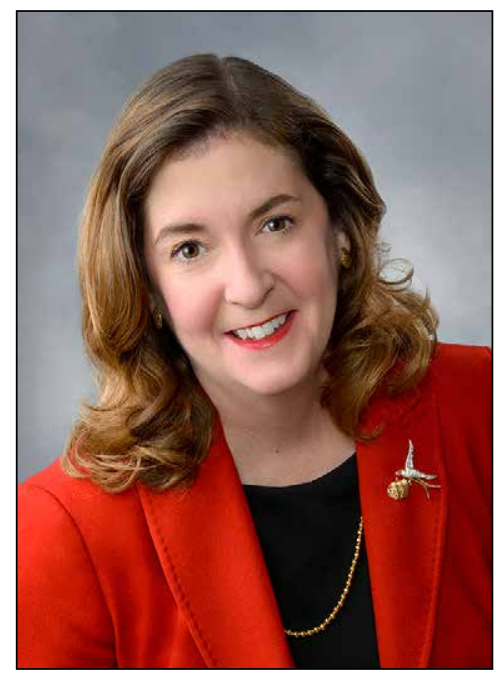

\title{
Association for Library Collections and Technical Services Annual Report 2013-14
} Genevieve S. Owens, 2013-14 ALCTS President

Comprising nearly four thousand members from across the United States and $\checkmark$ forty-two countries from around the globe, ALCTS is the premier resource for information specialists in collection development, preservation, and technical services. We are the leader in the development of principles, standards, and best practices for creating, collecting, organizing, delivering, and preserving information resources in all forms. This year, under the leadership of ALA President Barbara Stripling and ALCTS President Genevieve S. Owens, we have focused on three key areas: financial stability, organizational flexibility, and excellence.

\section{Financial Stability}

In celebration of the twenty-fifth anniversary of our name as the "Association for Library Collections and Technical Services," we launched a "25 Years of Awesome" campaign. This effort solicits contributions from members in three categories of giving.

\section{Twenty-Five Years of Awesome: Innovative Initiatives}

ALCTS, our name since 1989, celebrates its twenty-fifth birthday in 2014. The " 25 Years of Awesome" fund accepts unrestricted gifts for new and ongoing initiatives in such areas as, but not limited to, standards, advocacy, leadership development and international relations. Donations help secure the future growth of ALCTS, its services, member support and ongoing initiatives and ultimately position ALCTS in a central role for the library community, as we embark on our next twenty-five years.

\section{Preservation Week}

Get involved! Preservation Week was created because 630 million items in collecting institutions require immediate attention and care. Personal, family, and community collections are equally at risk.

As natural disasters of recent years have taught us, these resources are in is Library Director, Williamsburg (VA) Regional Library. 
Libraries and other institutions use Preservation Week to connect our communities through events, activities, and resources that highlight what we can do, individually and together, to preserve our personal and shared collections. Please visit the Preservation Week webpage for more information: www.ala.org/alcts/confevents/preswk.

\section{Our Best Work}

Consider a donation to ALCTS by making a gift to the "Our Best Work" fund! This fund supports new and ongoing initiatives specifically for program development, continuing education, publications, grants and awards. These initiatives will further enhance ALCTS' position and reputation for high-quality programming and publications essential to the library community.

To date, seventeen consecutive years of ALCTS presidents, past presidents, and presidents-elect have contributed to the campaign, as have two-thirds of the current ALCTS board. We look forward to extending the campaign to our full membership with these leadership gifts. In an effort to institutionalize a culture of giving, we have also incorporated the ALCTS fundraising chair as an ex-officio member of the finance committee.

This year, the ALCTS board voted to move our flagship journal, Library Resources and Technical Services, to an e-only publication model. This decision was not undertaken lightly. Instead, it was the result of extensive study under an ALA Emerging Leaders report and significant consideration by multiple ALCTS committees. Changes in the journal's publication have also sparked consideration of an open access policy, which the board anticipates passing in advance of the 2014 ALA Annual Conference in Las Vegas. We owe a debt of gratitude to ALCTS Past President Carolynne Myall for her leadership in this arena. The change to an e-only model will be effective in January 2015. We thank Editor Mary Beth Weber for her leadership in this transition.

Similar changes took place this year for ALCTS News. Our association's newsletter is now a continuously updated online publication with the purpose to report the news and activities of ALCTS and its members, and to be the voice of our association. We are grateful to Editor Alice Pearman for her extraordinary efforts to bring this new format to fruition.

\section{Organizational Flexibility}

This year marks the ascendency of two relatively new ALCTS committees. The Advocacy and Policy Committee is designed to:

Enable the Association to play a proactive and effective role in policy development and legislative influence in order to enhance and ensure ALCTS' contribution to the advancement of the profession and the improvement of library services.

The Standards Committee is designed:

To provide ongoing education to ALCTS members and other interested individuals in the information industry about relevant standards and to actively promote member involvement in the standards development process in part by maintaining close relationships with the Section Executive Committees. To collect and share information regarding current and developing standards within the scope for ALCTS, and to provide assistance to and support for the NISO representative.

Respective Chairs Olivia M. A. Madison and Jacquie Samples have provided exceptional leadership for both groups. The Advocacy and Policy Committee played a key role in the ALCTS/bepress Digital Commons Midwinter Symposium, "Here There Be Dragons: Public Access to Federally Funded Research."

\section{Excellence}

ALCTS has been actively involved in two areas of particular importance to ALA: member engagement and strategic planning. We have worked with our New Members Interest Group, our Membership Committee, and our Leadership Development Committee to explore ways we can better fold our members into the work of our association. Two particular events, "ALCTS 101" at each Annual Conference and the New Members Interest Group at each Midwinter Meeting help us welcome and engage new members in our Association.

Our Planning Committee is seeking how we can align ALCTS planning with that of ALA as a whole. We recognize that ALA's priorities play a significant role in our own.

Under the leadership of Felicity Dykas, ALCTS has distinguished itself in the area of continuing education. These efforts include webinars, e-forums, and web courses.

Our signature event, Preservation Week, took place April 17-May 3, 2014. Preservation Week connects our communities through events, activities, and resources that highlight what we can do, individually and together, to preserve our personal and shared collections.

This year we also mark the passing of two of our best and brightest, Mary Woodley and Birdie MacLennan. These women exemplified our highest standards and continued to be missed by all who knew them. 


\section{Don't Try This At Home}

On a personal note, this ALCTS president is compelled to acknowledge that serving one's association while becoming a first-time library director is not for the faint of heart. I am infinitely indebted to my executive committee (Past President Carolynne Myall, President-Elect Mary Page, Councilor Brian Schottlaender, and President-Elect-To-Be Norm Medeiros) for your wonderful support and good humor. All of us are further beholden to our exceptional ALCTS staff members, Christine McConnell and Julie Reese. Each and every day, Christine and Julie dance backward in high heels and make the whole production look effortless. And then there's Charles. Our executive director has the audacity to retire in February 2015 and the dedication to plan for it since 2012 or so. None of us can really imagine ALCTS without you, and we treasure your efforts to help us plan for it anyway. Thank you for the privilege of writing the last annual report on your watch.

With my most fond regards, Genevieve

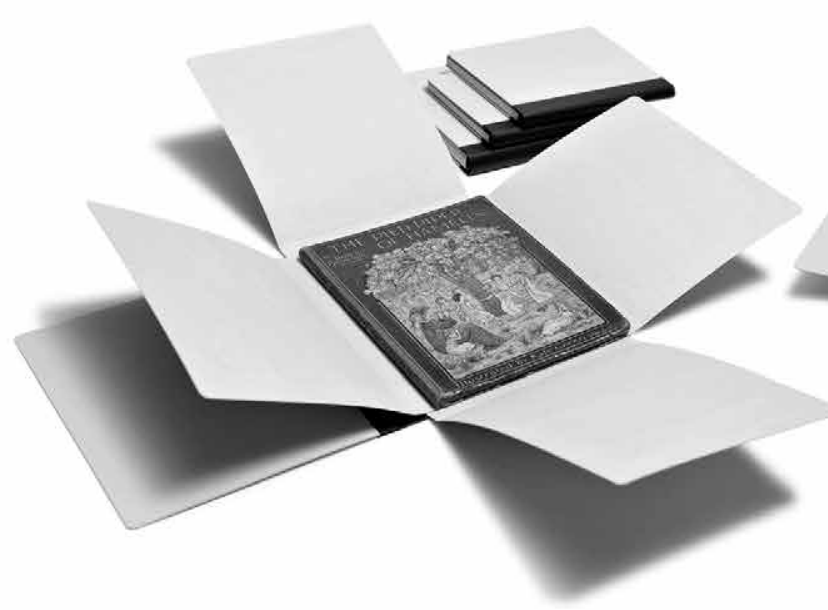

Preserve + Conserve + Quality

It's who we are, and what we deliver.

At Archival Products, we care about preserving your most important items. That's why we've developed an extensive product line to meet virtually every preservation need. All hand-crafted by our dedicated team. 